\title{
Tolloid-Like Protein 1
}

National Cancer Institute

\section{Source}

National Cancer Institute. Tolloid-Like Protein 1. NCI Thesaurus. Code C101409.

Tolloid-like protein 1 (1013 aa, $115 \mathrm{kDa}$ ) is encoded by the human TLL1 gene. This protein plays a role in both collagen maturation and skeletal development. 